\title{
Intraluminal supraglottic lesion presenting with stridor: an unlikely pathology
}

\author{
Stuti Chowdhary 지 , Arun Alexander
}

ENT, Jawaharlal Institute of Postgraduate Medical Education and Research, Puducherry, India

\section{Correspondence to} Dr Stuti Chowdhary: stuti.9894@gmail.com

Accepted 28 April 2021

\section{DESCRIPTION}

A 37-year-old man presented to the ENT outpatient clinic with progressive dysphagia and breathlessness on exertion for a year. The patient was tachypnoeic, with mild inspiratory stridor and orthopnoea. The neck had a generalised swelling, but no mass was clinically palpable. Indirect laryngoscopy showed a globular, pink mass partially obscuring the view of

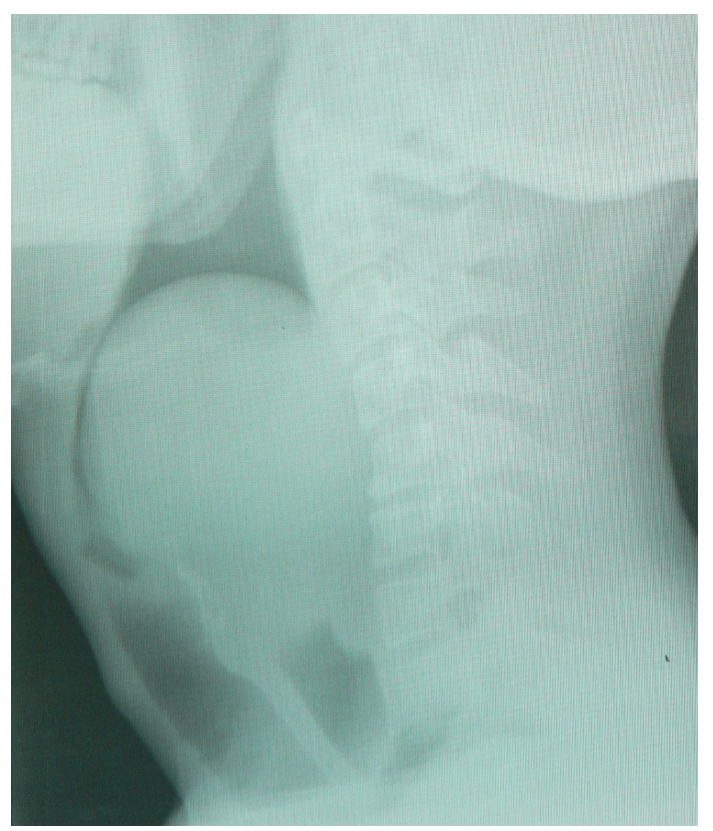

Figure 1 Plain lateral X-ray of the neck showing a smooth supraglottic mass completely blocking the airway.

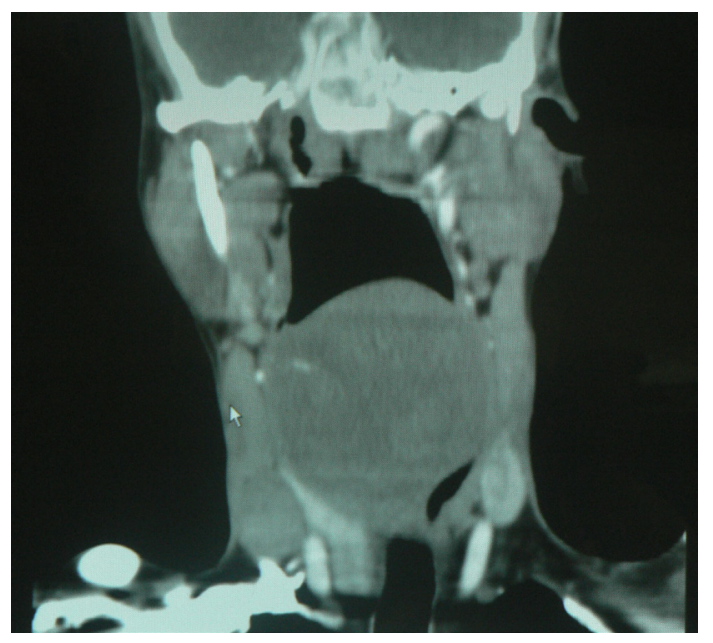

Figure 2 Contrast-enhanced CT scan (coronal section) showing a homogenous, hypointense lesion arising from the supraglottis.

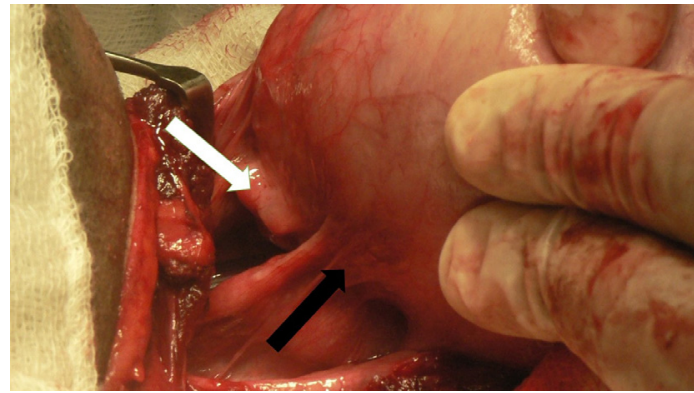

Figure 3 Intraoperative photograph showing the mucosa-covered, smooth ovoid lesion. The white arrow points towards the epiglottis. The black arrow shows the attachment of the lesion to the aryepiglottic fold.

the endolarynx. A plain lateral radiograph of the neck showed a smooth, oval supraglottic soft tissue mass significantly blocking the airway (figure 1). A contrast-enhanced CT scan of the neck showed a homogenous, hypointense lesion in the supraglottis, pushing the epiglottis anteriorly and partially covering the laryngeal inlet (figure 2).

Since the patient had had breathlessness for a year, he was able to tolerate the initial radiological investigations fairly well without the need for any emergency airway management. The patient underwent surgical excision of the mass based on the clinical and radiological findings, and as soon as baseline investigations were available and blood could be arranged. He was intubated using a flexible laryngoscope with a $6 \mathrm{~mm}$ endotracheal tube. The lesion was approached via a lateral pharyngotomy. The large intraluminal mass was arising from the right aryepiglottic fold and had a narrow pedicle (figure 3). The lesion appeared to arise from a thickened nerve present in its pedicle and was probably a branch of the superior laryngeal nerve. The lesion was excised in-toto. It was solid, measuring $9 \times 6 \times 6 \mathrm{~cm}$ and the cut section was yellow with a gritty surface. The wound was closed in layers and the patient was extubated at the end of the procedure.

Histopathological examination of the excised specimen revealed well-defined bundles of cells with spindle-shaped nuclei, forming the characteristic Verocay bodies. The sections were positive for S-100, thus confirming the diagnosis of a schwannoma. The patient had complete resolution of his symptoms postoperatively, and he remains symptom free without any neurological deficits like hoarseness or aspiration a year after his surgery.

The common causes for a presentation of inspiratory stridor in the adult population are malignant 
obstruction, neurological conditions such as vocal cord palsies and infectious causes. ${ }^{1}$ From the otolaryngologists' point of view, biphasic stridor in today's age is seen frequently due to acquired subglottic stenosis, as a sequela of prolonged endotracheal intubation. ${ }^{2}$ Schwannomas can cause hoarseness due to mass effect, dysphagia and dyspnoea, often progressing to biphasic stridor. ${ }^{3}$ Laryngeal schwannomas are rare, with a reported incidence of 15 out of 100000 of all benign laryngeal tumours. ${ }^{4}$ Schwannomas of the head and neck region usually arise in the parapharyngeal space or in syndromic association with neurofibromatosis. The symptoms are gradually progressive, owing to the slow-growing nature of the lesion. Laryngeal tumours of neurogenic origin arise more commonly from supraglottic structures. The aryepiglottic folds are the most commonly affected, followed by the true and false vocal cords. The internal branch of the superior laryngeal nerve has been frequently described as the nerve of origin. $^{5}$

A preoperative CT scan of the neck helps rule out parapharyngeal space involvement, which is commonly seen in neurofibromas. An MRI of the neck is the investigation of choice but

\section{Patient's perspective}

I am delighted the lump in my neck is not cancer. Now I have no shortness of breath, and I hope it never recurs again.

\section{Learning points}

A wide range of dynamic and obstructive lesions can precipitate stridor in an otherwise healthy individual. Rare causes such as laryngeal schwannomas should be kept in mind given the heterogeneous tissue distribution in the region.

- A tracheostomy is usually needed to secure an airway. However, a timely preoperative diagnosis and an appropriate surgical plan will avoid the morbidity associated with a tracheostomy, as seen in this case.

- Histopathological confirmation should be sought in all cases with an uncertain aetiology. may not be feasible in cases with respiratory distress. Fine-needle aspiration cytology yields valuable information for diagnosis in a clinically palpable mass in the neck. An intraluminal schwannoma, on the other hand, evades diagnosis until an emergency necessitates a neck exploration. Securing the airway should be the primary goal of management. Schwannomas are almost always solitary lesions and are encapsulated by a mucosal layer, facilitating complete enucleation. ${ }^{6}$

Definitive diagnosis is by histopathology, by immunohistochemical staining with S-100, which is specific for schwannomas. Neurofibromas have an inherently higher risk of malignancy and recurrence, as compared with schwannomas. A radical resection such as a total laryngectomy is, thus, not warranted in cases of intralaryngeal schwannomas. ${ }^{7}$ Due to tissue heterogeneity in the supraglottis, a wide range of differential diagnoses could be considered, including an epiglottic cyst, an intraluminal leiomyoma of the pharynx and a lipoma.

Contributors SC: drafting the manuscript, literature search. AA: critical review, approving the final version.

Funding The authors have not declared a specific grant for this research from any funding agency in the public, commercial or not-for-profit sectors.

Competing interests None declared.

Patient consent for publication Obtained

Provenance and peer review Not commissioned; externally peer reviewed.

\section{ORCID iDs}

Stuti Chowdhary http://orcid.org/0000-0003-2154-6400

Arun Alexander http://orcid.org/0000-0003-1026-4678

\section{REFERENCES}

1 Zochios V, Protopapas AD, Valchanov K. Stridor in adult patients presenting from the community: an alarming clinical sign. J Intensive Care Soc 2015;16:272-3.

2 Cathain E O, Gaffey MM. Upper Airway Obstruction. In: StatPearls. Treasure Island (FL): StatPearls Publishing, 2021

3 Ebmeyer J, Reineke U, Gehl H-B, et al. Schwannoma of the larynx. Head Neck Oncol 2009;1:24.

4 Jones SR, Myers EN, Barnes L. Benign neoplasms of the larynx. Otolaryngol Clin North Am 1984;17:151-78.

5 Ramakrishnan Y, Issing WJ. Laryngeal schwannoma: case report and literature review. ISRN Otolaryngol 2011;2011:1-3.

6 Rosen FS, Pou AM, Quinn FB. Obstructive supraglottic schwannoma: a case report and review of the literature. Laryngoscope 2002;112:997-1002.

7 Singh S, Kumar R, Roy M, et al. Glottic neurogenic tumor: a highly uncommon site for schwannomas. J Cancer Res Ther 2018;14:687-9.

Copyright 2021 BMJ Publishing Group. All rights reserved. For permission to reuse any of this content visit https://www.bmj.com/company/products-services/rights-and-licensing/permissions/

BMJ Case Report Fellows may re-use this article for personal use and teaching without any further permission.

Become a Fellow of BMJ Case Reports today and you can:

- Submit as many cases as you like

- Enjoy fast sympathetic peer review and rapid publication of accepted articles

- Access all the published articles

- Re-use any of the published material for personal use and teaching without further permission

Customer Service

If you have any further queries about your subscription, please contact our customer services team on +44 (0) 2071111105 or via email at support@bmj.com.

Visit casereports.bmj.com for more articles like this and to become a Fellow 